\title{
<技術論文 >
}

(受理：平成 30 年 10 月 30 日)

\section{粘着テープのピール強度におよぼす ステンレス鋼製被着体の洗浄法の影響}

岡田駿*・柏原 佑亮 *. 竹㟝愛*・浦濱 圭涁**・ 平井 智康 $* * *$ 藤井 秀司 $* * *$. 中村 吉伸 $* * *$

要 旨

粘着テープのピール強度におよぼすステンレス鋼（SS）被着体の洗浄法について検討した。ゴム系，アクリ ル系，スチレン系ブロックコポリマー，シリコーン系の 4 種の粘着テープと, SS 被着体のモデルとして同様 の作製法による SS 箔を用いた。熱洗浄（メチルエチルケトンを不織布に含ませて 3 回拭く $\rightarrow$ メエンで同様 の操作 $\rightarrow 175^{\circ} \mathrm{C}$ で $1 \mathrm{~h}$ 加熱 $\rightarrow$ メルエチルケトンとトルエンによる洗浄を再度行う) と超音波洗浄（トルエン中 で 1 h）を比較した結果，ピール強度の向上には，超音波洗浄より熱洗浄の方が効果的であった。X 線光電子 分光分析 (XPS) から，熱洗浄や超音波洗浄を行っても SS 箔表面にC 元素が多く存在し，放置によりさらに 増加する場合があった。SSの冷間圧延時に表面の凹部に封じ込まれた潤滑油が，放置時間にともなって表面 の細孔から染み出すためであると考えられる。潤滑油が污染物質である。ピール試験の安定化に，熱洗浄が

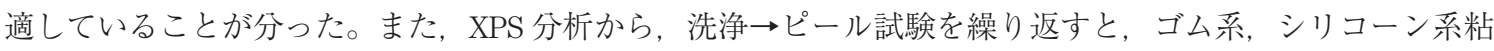
着剤は SS 箔表面に残る可能性があることが分った。

\section{1. 緒 言}

粘着テープのピール強度の測定条件は, JIS Z0237 で 詳細に決められている。この中でステンレススチール (SS) の標準被着体については, 同 JIS の 2000 年版では SUS304・\#360 研磨, 表面粗さ $\left(R_{\mathrm{a}}\right.$, 中心線平均粗さ) : 50 〜 $400 \mathrm{~nm}$ であったものが, 2009 年版では SUS304BA， $R_{\mathrm{a}}$ : $50 \pm 25 \mathrm{~nm}$ に変更されている。 $\mathrm{SS}$ 標準被着体は, 冷間圧 延で表面加工される。冷間圧延とは，SS 板を常温でロー ルを通す圧延加工で，板厚が均一化されるとともにロール 表面の平滑性が転写される ${ }^{1)}$ 。BA は冷間圧延後にさらに 光輝度を高める処理を行ったものである ${ }^{1)}$ 。上記の変更は, 冷間圧延技術の発展により, SS 表面の平滑性が向上した

* 大阪工業大学工学部応用化学科 大阪市旭区大宮 5-16-1 于 535-8585

** 兵庫県立大学大学院工学研究科 姫路市書写 2167 于 671-2201

****大阪工業大学工学部応用化学科 大阪工業大学ナノ材料マイクロデバイス研究センター 大阪市旭区大宮 5-16-1 于 535-8585 (原稿受付日：平成 30 年 9 月 10 日)
ためと考えられる ${ }^{2)}$ 。粘着テープメーカーは $R_{\mathrm{a}}$ をピール 強度に影響する重要な因子と考え, $R_{\mathrm{a}}$ 測定とピール強度 との関係のラウンドロビン・テストが日本粘着テープ工業 会加入の各社で行われている ${ }^{3)}$ 。その結果, 市販の SS 被 着体の $R_{\mathrm{a}}$ は規格の $50 \pm 25 \mathrm{~nm}$ の下限付近あるいはそれ 以下のものがほとんどであったので範囲が狭く， $R_{\mathrm{a}}$ とピー ル強度の関係は明確にされていない3)。

また, 同JISにはSS 被着体の洗浄溶剂の種類や洗浄法 についても記載されており, 溶剤を脱脂綿等に含ませて拭 くように決められている。ところが, 粘着テープメーカー では, アメリカ粘着テープ工業会 (PSTC) の推奨法とし て $175^{\circ} \mathrm{C} て ゙ 1 \mathrm{~h}$ 加熱する熱洗浄が，広く検討されている ${ }^{3)} 。$ 熱洗浄では, 加熱の前後に不織布を用いてトルエンとメチ ルエチルケトン $(\mathrm{MEK})$ で 3 回ずつ拭かれている ${ }^{3)}$ 。この ような熱洗浄を行う理由や効果については, 十分な情報が ない。

本報告では, ピール強度に影響する $\mathrm{SS}$ 被着体の因子と して洗浄法と $R_{\mathrm{a}}$ について検討した。 $\mathrm{SS}$ 被着体のモデル材 として，同様の作製方法によるSS 箔を用いた。これは， 日本粘着テープ工業会より提供されたもので, より幅広い $R_{\mathrm{a}}$ を有している。粘着テープは, ベースポリマーの異な 
る 4 種類の市販品を用いた。SS 笪表面の X 線光電子分光 分析 (XPS) を行い, 最適の洗浄法と污染源を明らかにし ようとした。

\section{2. 実験方法}

\section{1 試料}

Table 1 には, SS 被着体のモデルとしての 4 種類の SS 箔（SUS304 製，日本金属(株) を示した。これらは，日本粘 着テープ工業会より提供された。記号末尾の BA は上述, $\mathrm{H}$ は高硬度材, TA はさらに内部応力低減の熱処理を行っ たものである ${ }^{1)}$ 。SS 箔の冷間圧延後の後処理は, SS-1 と SS-2 が BA 処理で 2009 年版の JIS Z0237で規定されてい る標準被着体と同じであるが, SS-3 と SS-4 は異なる。こ れは，幅広い $R_{\mathrm{a}}$ の影響を検討するために，やむをえず後 処理の異なる SS 箔も用いたためである。 $R_{\mathrm{a}}$ 值の小さいも のは冷間圧延の回数が多い。Table 2 には, 使用した 4 種 類の粘着テープを示した。粘着剂のベースポリマーは, ゴ ム系, アクリル系, スチレン系ブロックコポリマー, シリ コーン系である。溶媒として市販の試薬級の MEK とトル エンを使用した。

\section{$2.2 \mathrm{SS}$ 箔の洗浄処理}

污染物質の影響を検討するために, ピール試験の前に熱 洗浄あるいは超音波洗浄を行った。

\subsection{1 熱洗浄}

保護フィルムを剥がした SS 箔を, 不織布 (Bemcot, 小 津産業(株)にＭEKを含ませて 3 回拭き，ついでトルエン で同様に 3 回拭いた。これを $175^{\circ} \mathrm{C} て ゙ ~ 1 \mathrm{~h}$, 乾燥機中で加 熱した。室温に戻した後に, 再びMEK とトルエンで 3 回 ずつ拭いた。

\section{2 .2 超音波洗浄}

保護フィルムを剥がした SS 箔を,ステンレス製のトレー に重ならないように入れ，トルエンに浸漬させた。アルミ
ホイルと食品用ラップフィルムで蓋をし，ガムテープで封 じて卓上型超音波洗浄装置 (Bransonic 5510J-MT, $40 \mathrm{kHz}$, 日本エマソン(株) を用いて, $23^{\circ} \mathrm{C}$ で $1 \mathrm{~h}$ 超音波洗浄を行った。

\section{3 ピール強度}

被着体の洗浄の効果や $R_{\mathrm{a}}$ の影響を検討するために, ピー ル強度を測定した。 $50 \mathrm{~mm}$ 幅に切断した SS 箔表面上に, 粘着テープを $25 \mathrm{~mm}$ 幅に切断して載せ, $2 \mathrm{~kg}$ の鉄製のロー ラ（表面はゴムシート）を 1 往復して圧着した。Table 2 の粘着テープのうち, Tape A, D は SS 箔にそのまま貼り 付けた。Tape B, C はテープ幅が $50 \mathrm{~mm}$ のためにセパレー タに貼って $25 \mathrm{~mm}$ 幅に切断した後, SS 箔に貼り付けた。

$180^{\circ}$ ピール試験は, JIS Z 0237 にしたがって引張試験 機（EZ-LX，株島津製作所）を用いて $5 \mathrm{~mm} / \mathrm{s}$ で温度一定 $\left(23^{\circ} \mathrm{C}\right)$ で行った。試験片作製後，20 分後にピール試験を 行った。試験開始後, 一定荷重ではく離が進行するように なってからの 3 本の試験片の荷重の平均值からピール強度 をもとめてプロット点とした。その範囲の測定值の最大值 と最小值をエラーバーで示した。

\subsection{XPS 分析}

污染物質を特定するために, SS 箔を $1 \mathrm{~cm}$ 角に切断し, X 線光電子分光分析装置 (Axis Ultra, (株)島津製作所) を用 い, X 線 Monochromated $\mathrm{Al} \mathrm{K} \alpha$, 真空度 $1.0 \times 10^{-6} \mathrm{~Pa}$ で表面の元素を分析した。C $1 \mathrm{~s}$ のピークを $285 \mathrm{eV}$ に合わ せた。

\section{5 污染物質の検討}

污染物質の発生源を特定するために, 熱洗浄あるいは超 音波洗浄した SS-2 被着体について，36日間室温で実験室 に放置，あるいはデシケータ中で放置の後処理を行った。 洗浄処理なしのサンプルも加えた計 7 種類の SS-2 被着体 の表面をXPS で分析した。

Table 1 Four kinds of SS foils.

\begin{tabular}{ccccc}
\hline Code & $\begin{array}{c}\text { Quality of the material } \\
\text { and processing }\end{array}$ & $\begin{array}{c}\text { Thickness } \\
(\mathrm{mm})\end{array}$ & $\begin{array}{c}\text { Surface roughness, } R_{\mathrm{a}} \\
(\mathrm{nm})\end{array}$ & Lot. No. \\
\hline SS-1 & SUS304-BA & 0.2 & 22 & $\# 21515-06$ \\
SS-2 & SUS304-BA & 0.1 & 52 & $\# 27677-04$ \\
SS-3 & SUS304-HTA & 0.1 & 65 & $\# 26668-22$ \\
SS-4 & SUS304-H & 0.2 & 95 & $\# 29581-08$ \\
\hline
\end{tabular}

Table 2 Four kinds of commercial available PSA tapes.

\begin{tabular}{clllll}
\hline Code & \multicolumn{1}{c}{ Base polymer } & Backing & Product No. & Manufacture company & Tape width (mm) \\
\hline Tape A & Rubber & Cellophane & CT-24 & Nichiban Co., Ltd. & 24 \\
Tape B & Acrylic polymer & PET & $\# 31 \mathrm{~B}$ & Nitto Denko Corp. & 50 \\
Tape C & Styrenic block copolymer & PP & \#372HQ & 3M Company & 50 \\
Tape D & Silicone polymer & PET & No. 6260 & Maxell Sliontec Ltd. & 25 \\
\hline
\end{tabular}




\section{6 ピール試験繰り返しによる污染の検討}

ピール試験後にSS 被着体を洗浄し, 繰り返して使用す る場合の污染の蓄積を評価するために, SS-2 被着体の洗 浄処理 (熱洗浄あるいは超音波洗浄) $\rightarrow$ ピール試験を計 3 回繰り返した後, XPS で表面分析を行った。ピール試験は, Tape A〜Dの 4 種類の粘着テープについて行った。熱洗 浄の場合は, ピール試験の後,つぎの熱洗浄を 2 日後に行つ た。超音波洗浄の場合は連続して行った。

\section{$2.7 \mathrm{SS}$ 箔の $R_{\mathrm{a}}$}

被着体の表面粗さの指標として，入手後そのままおよび 熱洗浄後の $R_{\mathrm{a}}$ を測定した。 $\mathrm{SS}$ 箔を $1 \mathrm{~cm}$ 角に切断し, 原 子間力顕微鏡 $(\mathrm{AFM}, \mathrm{AFM} 5100 \mathrm{~N}$, 日立ハイテクサイエン ス(株) を用いてタッピングモードで $100 \times 100 \mu \mathrm{m}$ の範囲 の凹凸を測定した結果から $R_{\mathrm{a}}$ を算出した。表面粗さ計に よる通常の方法では, ラインプロファイルから算出する。 3 箇所の測定を行い, 平均值を示した。 $\mathrm{AFM}$ の $\mathrm{Si}$ 製カン チレバーのバネ定数は $14 \mathrm{~N} / \mathrm{m}$, 先端半径は $7 \mathrm{~nm}$ である。

\section{3. 結果と考察}

\section{$3.1 \mathrm{SS}$ 箔の洗浄法の影響}

$\mathrm{SS}$ 箔の洗浄法として, 熱洗浄と超音波洗浄について検 討した。熱洗浄は $175^{\circ} \mathrm{C}$ の乾燥機中で $1 \mathrm{~h}$ 加熱し, その前 後に不織布を用いて MEK とトルエンでそれぞれ 3 回拭い た。2009年版の JIS Z0237では, 2 種類の溶剤で洗浄を行い, 1 種類はMEK かアセトンと決められている。同 JISには
トルエンが除かれているが, 経験的に洗浄能力が高いため に粘着テープメーカーの洗浄試験で用いられている ${ }^{3)}$ 。超 音波洗浄は, SS 筞をトルエンに浸漬して超音波洗浄機で $23^{\circ} \mathrm{C}, 1 \mathrm{~h}$ 洗浄処理を行った。上述のように経験的に洗浄 能力が高いために, トルエンを選んだ。洗浄の効果をピー ル強度で比較した。

Fig. 1 には, Tape A (ゴム系) を用いて 4 種の SS 箔の洗 浄のピール強度への影響を示した。ピール強度の測定值に エラーバーを付けているが, すべてマークに隠れている。 熱洗浄は， SS-1（a）， SS-2（b) でピール強度がわずかに向 上, SS-3 (c)， SS-4 (d) で，その効果がより高かった。ま た, 1 回で効果があり, 2 回行ってもさらなる向上はなかっ た。超音波洗浄は, 効果が低かった。

Fig. 2 には, Tape B（アクリル系）の結果を示した。 Fig. 1 の Tape A と比較して, 熱洗浄の効果はより高かっ た。 SS-1（a）， SS-2（b)より SS-3（c)， SS-4（d）の方が, 効果がより顕著であった。超音波洗浄は, $\mathrm{SS}^{-1}$ (a)でわず かの向上が見られたのみである。

Fig. 3 には, Tape C (スチレン系ブロックコポリマー) の結果を示した。熱洗浄の効果は, SS-1 (a), SS-2（b)で は小さかったが, SS-3（c)， SS-4（d）では明確に表れてい た。超音波洗浄の効果は, いずれも低かった。

Fig. 4 には, Tape D (シリコーン系) の結果を示した。 Tape $\mathrm{A} \sim \mathrm{C}$ と異なり, 熱洗浄, 超音波洗浄ともにピール 強度向上の効果がまったくなかった。これはシリコーン系 粘着剂が污染を有する表面に対しても，高い粘着性を示す
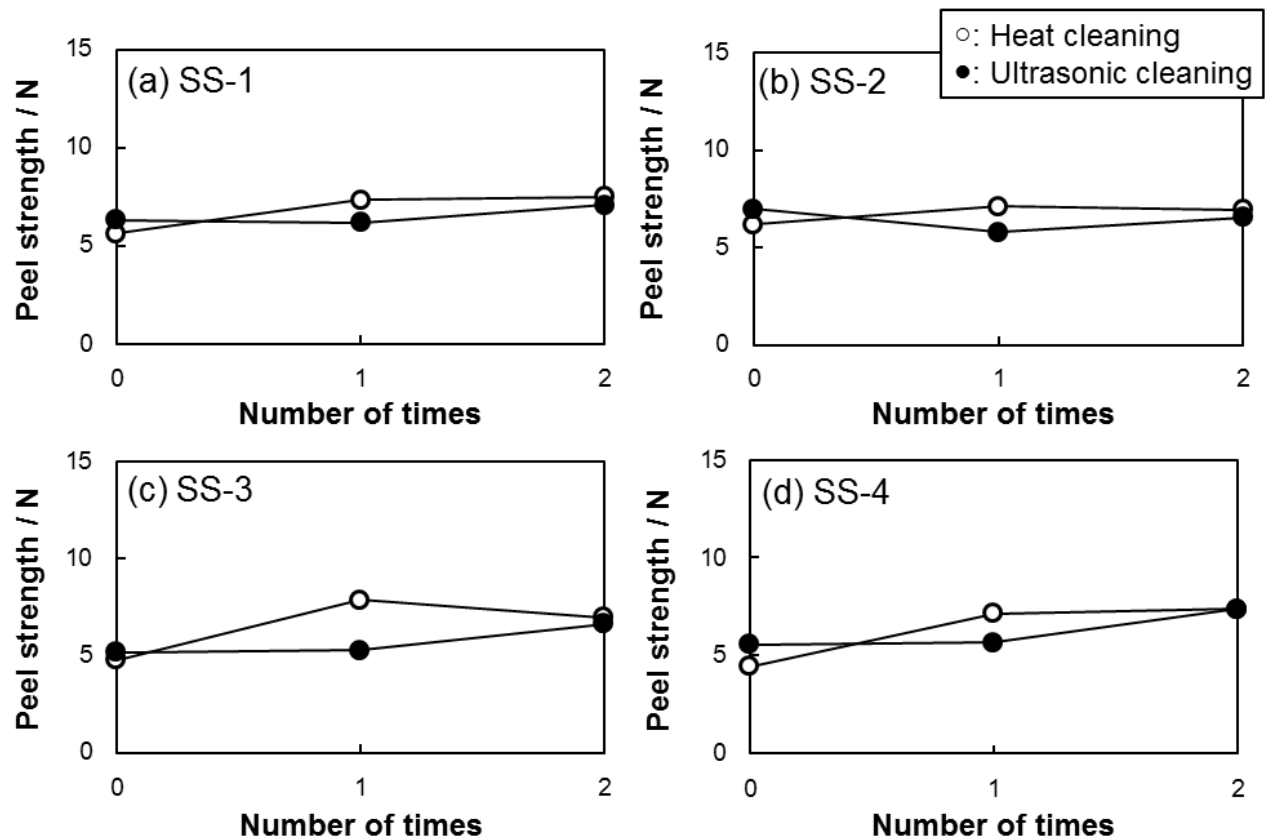

Tape A

Fig. 1 Effects of cleaning method, number of cleaning times and kind of SS foils on peel strength for Tape A. The width of tape is $24 \mathrm{~mm}$. 

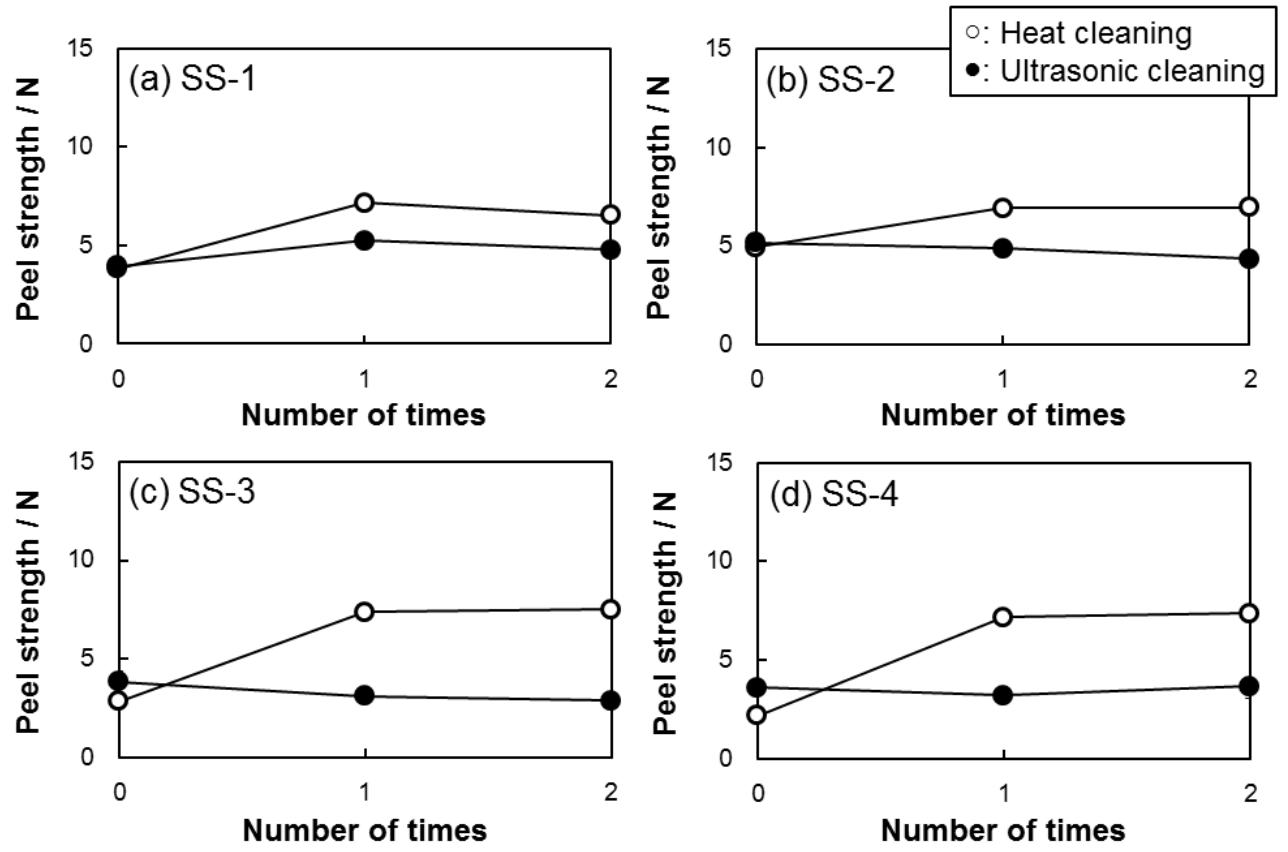

Tape B

Fig. 2 Effects of cleaning method, number of cleaning times and kind of SS foils on peel strength for Tape B. The width of tape is $25 \mathrm{~mm}$.
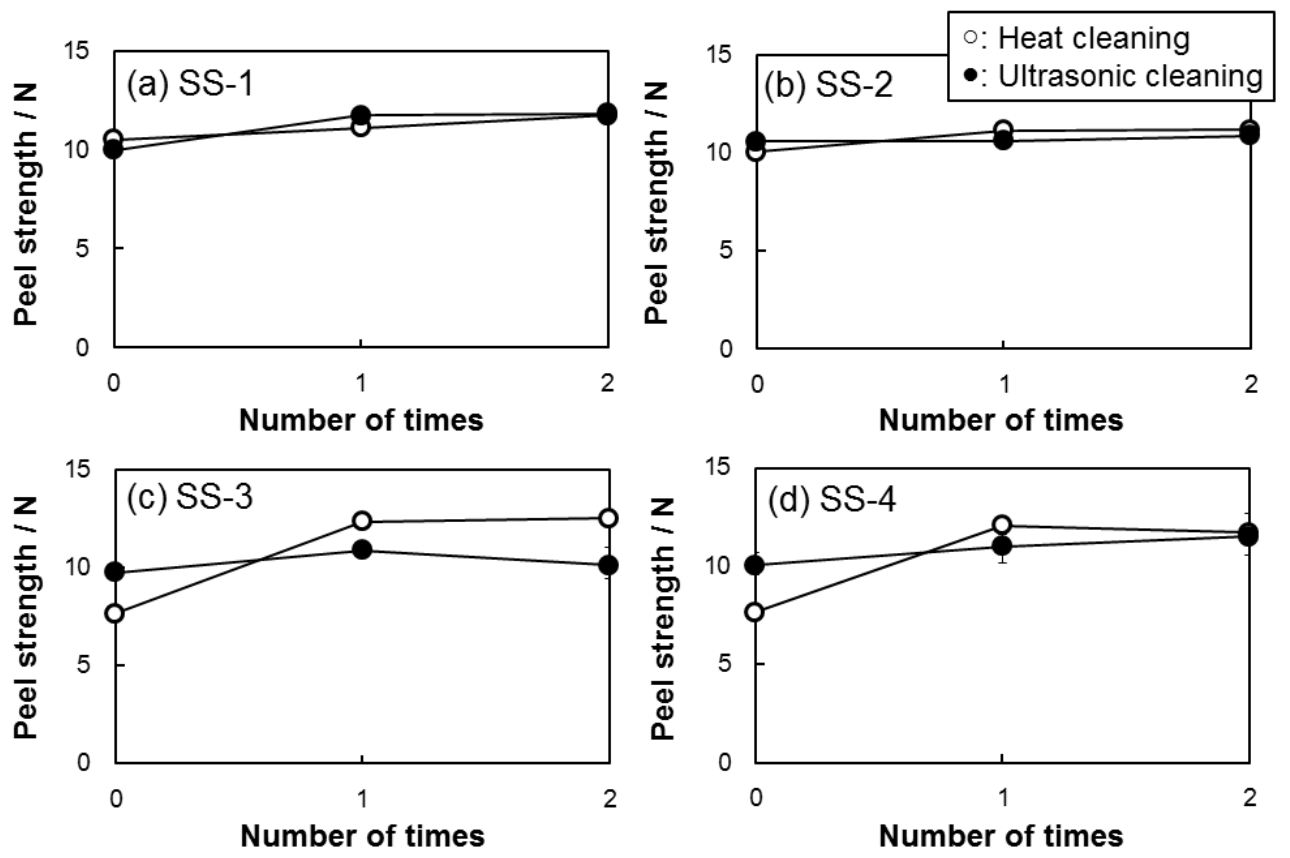

Tape C

Fig. 3 Effects of cleaning method, number of cleaning times and kind of SS foils on peel strength for Tape C. The width of tape is $25 \mathrm{~mm}$.

ためと考えられる。

以上のように, SS 箔の洗浄法として熱洗浄の方が超音 波洗浄より有効であることが分った。Tape A 〜 C で熱洗 浄の効果が，SS-3，SS-4>SS-1，SS-2であったのは, SS-3， SS-4 の方が污染の程度が高かったためと考えられ る。また、シリコーン系粘着剤では両洗浄法ともに効果が
なかった。なお，Tape A は幅が $24 \mathrm{~mm}$ (他は $25 \mathrm{~mm}$ )であ るが，幅の補正をせずに測定值をそのまま示している。粘 着強さは, 基材の種類 (弾性率), 粘着剂層や基材の厚さ にも大きく影響される。以上の理由で, 本報告でのピール 強度は, 同一粘着テープ内の比較に留める。 

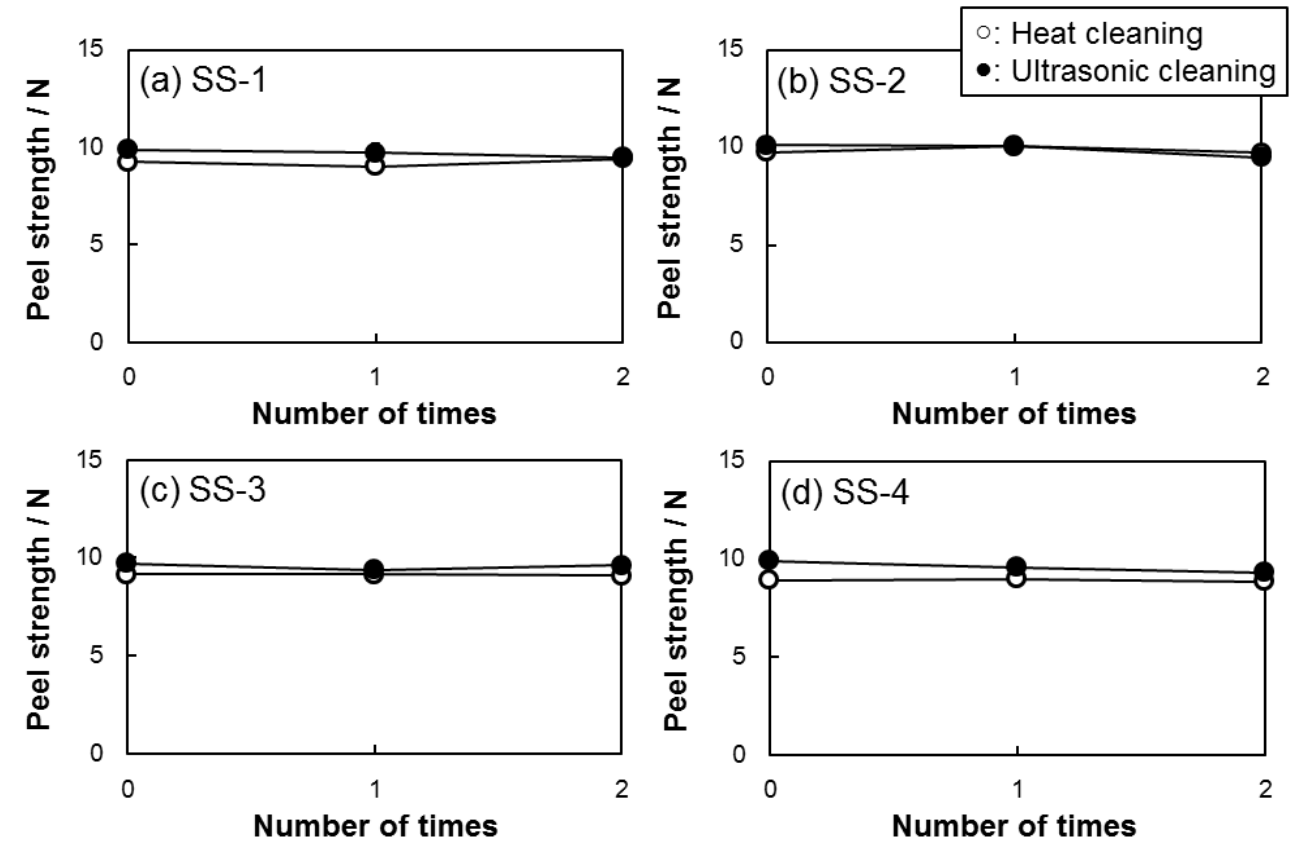

Tape D

Fig. 4 Effects of cleaning method, number of cleaning times and kind of SS foils on peel strength for Tape D. The width of tape is $25 \mathrm{~mm}$.

\section{2 污染物質の特定}

污染源を明らかにするために，保護フイルムを剥がし て熱洗浄あるいは超音波洗浄を行い, さらに 36 日間室温 で実験室，またはデシケータ中に放置した SS 箔について XPS 分析を行った。なお, これ以降の検討は，標準 SS 被 着体と後処理が同じ BA 処理の SS-2のみについて行った。

Fig. 5 には，XPS スペクトルを示した。保護フィルムを 剥がした後には (a)， Fe， Cr， O , N ， C, Si のピークが出
現していた。SUS304の主成分は, Cr $(18 〜 20 \%), \mathrm{Ni}(8$ 〜 11\%), Fe (残り) でその他微量成分が含まれるが, C は

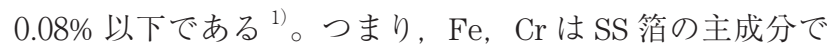
あり，Si は保護フィルムに由来する。本来微量の C が污 染源と考えられる。熱洗浄 (b) や超音波洗浄 (e) 後でも, ピークは同様で C 元素が存在した。

Table 3 には, XPS 結果 (Fig. 5) による SS 箔表面の元 素組成比を示した。保護フィルムを剥がした後の（a）の C 含有率は約 49\% で, 熱洗浄（b）や超音波洗浄（e）後でも

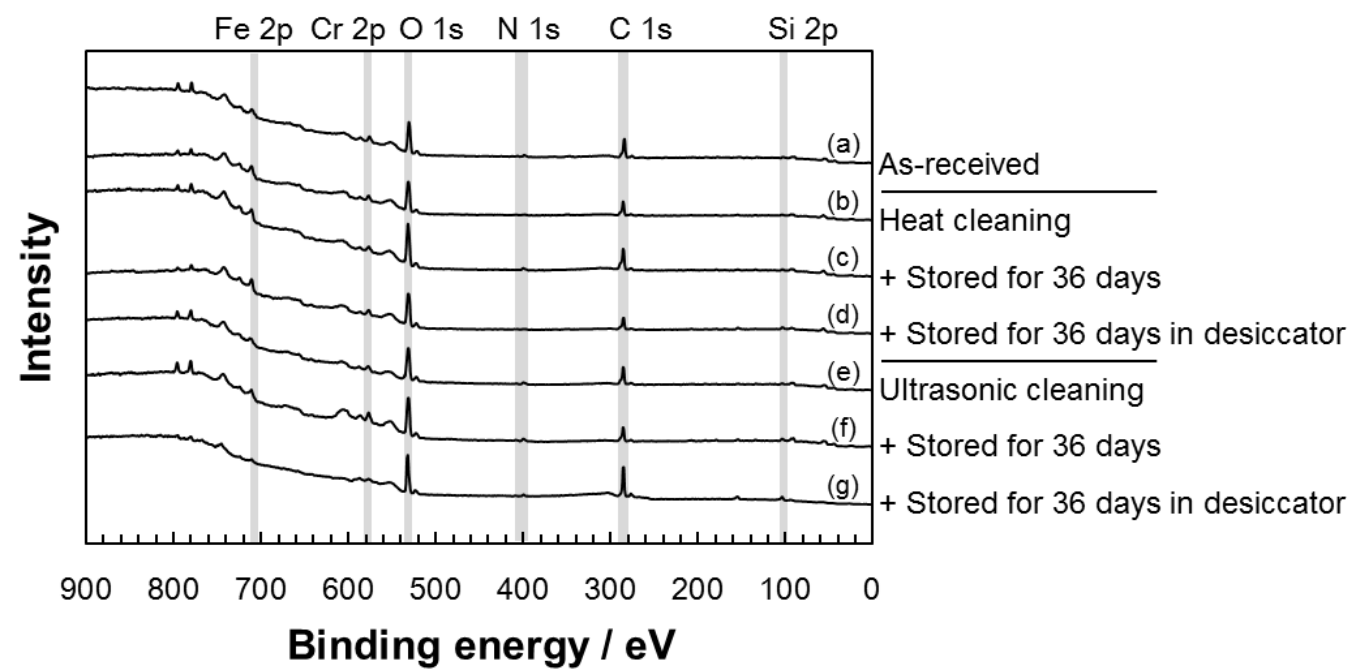

Fig. 5 XPS spectra for SS-2 foil surface (a) as-received, (b, e) after cleaning and (c, d, f, g) after cleaning and further storage. 
Table 3 Surface atomic compositions measured by XPS for SS-2 foil as-received, after cleaning and after cleaning and further storage.

\begin{tabular}{llcccccc}
\hline & Cleaning and storage & $\mathrm{Si}$ & $\mathrm{C}$ & $\mathrm{N}$ & $\mathrm{O}$ & $\mathrm{Cr}$ & $\mathrm{Fe}$ \\
\hline (a) & As-received & 3.40 & 48.68 & 2.44 & 35.60 & 2.85 & 7.03 \\
(b) & Heat cleaning & 1.21 & 39.81 & 1.96 & 42.15 & 4.46 & 10.41 \\
(c) & $\rightarrow$ Stored for 36 days & 2.84 & 47.30 & 2.74 & 36.72 & 2.74 & 7.66 \\
(d) & $\rightarrow$ Stored for 36 days in desiccator & 3.68 & 34.90 & 1.88 & 45.54 & 3.50 & 10.49 \\
(e) & Ultrasonic cleaning & 1.91 & 42.89 & 3.93 & 40.60 & 3.17 & 7.50 \\
(f) & $\rightarrow$ Stored for 36 days & 3.62 & 33.10 & 4.52 & 43.09 & 4.44 & 11.23 \\
(g) & $\rightarrow$ Stored for 36 days in desiccator & 10.80 & 52.79 & 2.70 & 28.38 & 1.47 & 3.86 \\
\hline
\end{tabular}

それぞれ約 40\%, 約 33\% と, 洗浄前 (a) より減少してい るが,ややり高い。熱洗浄 (b) や超音波洗浄 (e) 後は, 洗 浄前（a）と比較して Cr や Fe が増加しているので，表面 の污染物質は一部除去されている。Table 3 では, 熱洗浄 （b）や超音波洗浄（e）後に実験室内 $(\mathrm{c}, \mathrm{f})$ やデシケータ中 (d, g) で 36 日間放置した場合, C の含有率が洗浄後より 増加している場合があった。污染物質が, SS-2 内部より 染み出ている可能性を示している。

この点に関して, 札軒ら ${ }^{2)}$ は以下のように説明してい る。ステンレス鋼は冷間圧延によって表面が平滑化される が，このとき潤滑油が用いられる。この過程で元のステン レス鋼の凹部に潤滑油が封じ达められ, 冷間圧延後に残っ た細孔から潤滑油が染み出す。この潤滑油が SS 被着体の 污染源で, 本報告のピール試験とXPS の結果は, SS 被着 体表面の潤滑油の濃度を低下させるのに熱洗浄が効果的で あるが，その後も内部より染み出すことを示している。卜 ルエンによる超音波洗浄では潤滑油が十分に除去されず, $175^{\circ} \mathrm{C}, 1 \mathrm{~h}$ の熱洗浄では分解, 蒸発するものと考えられる。
ピール試験の安定化のために, 熱洗浄が効果的であること が分った。

増田 ${ }^{3)}$ は, 熱洗浄後の放置日数の増加にともなってピー ル強度が低下することを明らかにしている。この結果も, 潤滑油の染み出しが污染の原因であることを示している。

なお, Table 3 の洗浄後のデシケータ中での放置で, $\mathrm{Si}$ が増加していた。冷間圧延の一般的な潤滑油は佐伯 ${ }^{4)}$ が解 説しているが，本報告の SS 箔作製時の潤滑油やその洗浄 方法についての情報が得られていないので, この原因は不 明である。SS 箔表面の全反射測定 (ATR) 法によるフーリ 工変換赤外分光分析 (FT-IR) を行った結果, 污染物の存 在は示されたが, 微量であるために構造に関する情報は得 られなかった。

\section{3 ピール試験の繰り返しによる污染}

つぎに，SS 被着体を洗浄して繰り返して使用する場合 の，粘着剤の付着による污染を検討した。2.7 項に示した ように, 洗浄とピール試験を 3 回繰り返した後の SS 箔の

$$
\text { Cleaning } \rightarrow \underset{(1 \mathrm{st})}{\text { Peel test }} \rightarrow \text { Cleaning } \rightarrow \underset{(2 \mathrm{nd})}{\rightarrow} \text { Peel test } \rightarrow \text { Cleaning } \rightarrow \underset{(3 \mathrm{rd})}{\rightarrow} \text { Peel test } \rightarrow \text { XPS }
$$

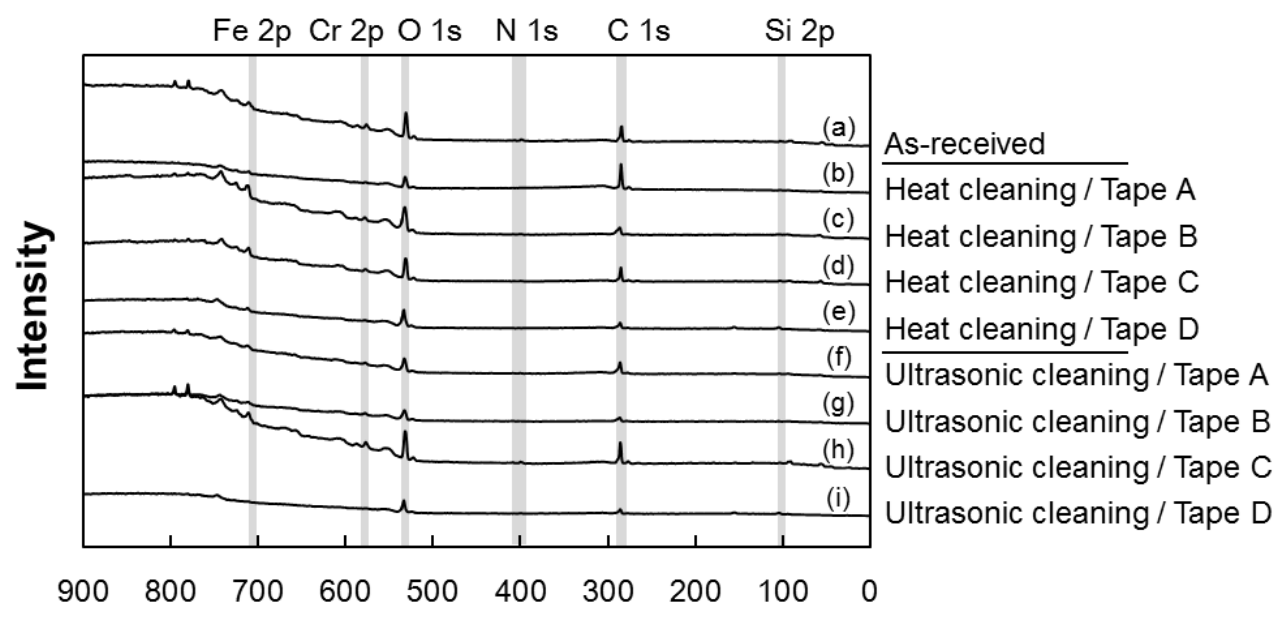

Binding energy / eV

Fig. 6 XPS spectra for SS-2 foil surface (a) as-received and (b-i) after three cycles of cleaning and peel test. Cleaning methods were (b-e) the heat cleaning and ( $\mathrm{f}-\mathrm{i})$ the ultrasonic cleaning. 
Table 4 Surface atomic compositions measured by XPS for SS-2 foil as-received and after three cycles of cleaning and peel test.

\begin{tabular}{|c|c|c|c|c|c|c|c|}
\hline & Cleaning and peel test & $\mathrm{Si}$ & $\mathrm{C}$ & $\mathrm{N}$ & $\mathrm{O}$ & $\mathrm{Cr}$ & $\mathrm{Fe}$ \\
\hline \multirow[t]{2}{*}{ (a) } & As-received & 3.40 & 48.68 & 2.44 & 35.60 & 2.85 & 7.03 \\
\hline & Heat cleaning and peel test & & & & & & \\
\hline (b) & with Tape A & 2.26 & 75.58 & 0.00 & 18.08 & 1.11 & 2.97 \\
\hline (c) & with Tape B & 2.55 & 37.54 & 0.00 & 44.96 & 2.55 & 12.41 \\
\hline (d) & with Tape C & 3.65 & 46.86 & 1.42 & 37.24 & 1.39 & 9.44 \\
\hline \multirow[t]{2}{*}{ (e) } & with Tape D & 5.10 & 41.60 & 3.86 & 40.97 & 3.00 & 5.43 \\
\hline & Ultrasonic cleaning and pee & & & & & & \\
\hline (f) & with Tape A & 2.45 & 57.80 & 2.69 & 25.94 & 3.26 & 7.86 \\
\hline (g) & with Tape B & 2.14 & 43.97 & 2.95 & 38.57 & 3.87 & 8.49 \\
\hline (h) & with Tape C & 1.79 & 45.87 & 3.10 & 35.17 & 4.23 & 9.84 \\
\hline (i) & with Tape D & 15.52 & 37.55 & 2.11 & 41.21 & 2.30 & 1.30 \\
\hline
\end{tabular}

Procedure of cleaning and peel test:

Cleaning $\rightarrow$ Peel test $\rightarrow$ Cleaning $\rightarrow$ Peel test $\rightarrow$ Cleaning $\rightarrow$ Peel test $\rightarrow$ XPS

(1st)

(2nd)

XPS 分析を行った。

Fig. 6 には，保護フィルムを剥がした直後，洗浄とピー ル試験を 3 回繰り返した後の SS 䇴表面の XPS 分析結果を 示した。Table 4 には，元素比を示した。熱洗浄と Tape A のピール試験後（b）は, C が増加して Cr や Fe が減少した。 超音波洗浄と Tape A のピール試験後 (f) も C が増加した。 潤滑油も C を増加させるが, 増加の程度を他と比較する とゴム系粘着剤の付着の影響と考えられる。Tape Dのピー ル試験後は, 熱洗浄, 超音波洗浄ともに Si が増加した。 シリコーン系粘着剤の付着を示している。熱洗浄, 超音波 洗浄ともに Tape B や Tape C では, このような変化は見ら れなかった。粘着剤の種類により SS 箔表面への付着性が 異なり，ゴム系やシリコーン系粘着剤は多いようである。

\section{$3.4 \mathrm{SS}$ 箔の表面粗さの影響}

$\mathrm{SS}$ 箔の洗浄は, 3.1 項で洗浄によるピール強度向上の効 果が高かった熱洗浄のみを行った。Fig. 7 には, SS 箔の 熱洗浄前後の $\mathrm{AFM}$ 測定による $R_{\mathrm{a}}$ を示した。 4 種の $R_{\mathrm{a}}$ は $\mathrm{SS}-4>\mathrm{SS}-3>\mathrm{SS}-2>\mathrm{SS}-1$ であったが，未洗浄の SS-2 と SS-3の $R_{\mathrm{a}}$ は, わずかに逆転していた。洗浄前後の明確 な差は見られなかった。2009 年版 JIS Z0237で規定されて いる $R_{\mathrm{a}}$ は $25 〜 75 \mathrm{~nm}$ であり，Fig. 7 の測定值はこの全範 囲にほぼ等しい。JIS 規定の幅広い $R_{\mathrm{a}}$ でピール強度への影 響を検討した。

Fig. 8 には，ピール強度におよぼす SS 箔の $R_{\mathrm{a}}$ の影響を 示した。未洗浄 (a) のピール強度の線は, SS-1 と SS-2, SS-3 と SS-4 をそれぞれ結んでいる。Tape D 以外, 明ら かに SS-1, SS-2> SS-3, SS-4であったが, SS-2 と SS-3 の $R_{\mathrm{a}}$ が同等であるにもかかわらずピール強度が異なった。 つまり，この原因は $R_{\mathrm{a}}$ の影響ではない。3.1で述べたよ うに, SS-3 と SS-4の污染の程度がより高いことに基づい ていると考えられる。熱洗浄後（b）は，このような $\mathrm{SS}-1$,

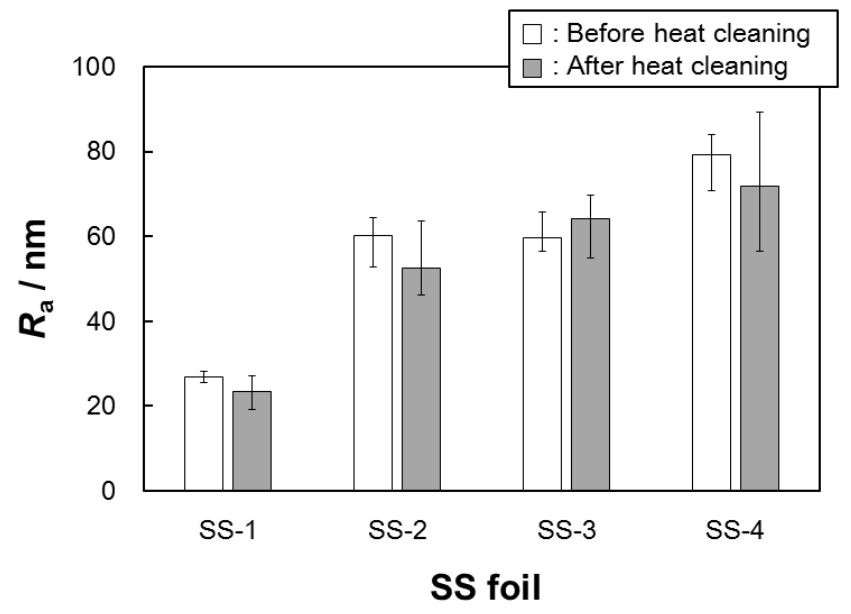

Fig. 7 Surface roughness, $R_{a}$ of SS foils measured by AFM before and after the heat cleaning.

SS-2 と SS-3， SS-4の差がなかったが， $R_{\mathrm{a}}$ の明確な影響 は見られなかった。つまり, SS 箔の污染の影響と比較して, $R_{\mathrm{a}}$ のピール強度への影響は小さいことが分った。

\section{4. 結 言}

粘着テープのピール強度におよぼす SS 被着体の洗浄法 と $R_{\mathrm{a}}$ の影響について検討した。 4 種の市販粘着テープと， $\mathrm{SS}$ 被着体のモデルとしての 4 種の SS 箔を用いて検討した。 以下の結果が得られた。

（1）污染の洗浄法としての熱洗浄（メチルエチルケトンを 不織布に含ませて 3 回拭く $\rightarrow$ ルエンで同様の操作 $\rightarrow 175^{\circ} \mathrm{C}$ で $1 \mathrm{~h}$ 加熱 $\rightarrow$ 溶剂による洗浄を再度行う）と 超音波洗浄（トルエン浸漬, $1 \mathrm{~h}$ ) を比較した。熱洗浄 ではピール強度が向上し, 超音波洗浄の効果は低かっ た。ピール試験の安定化のために, 熱洗浄が効果的で あることが分った。 

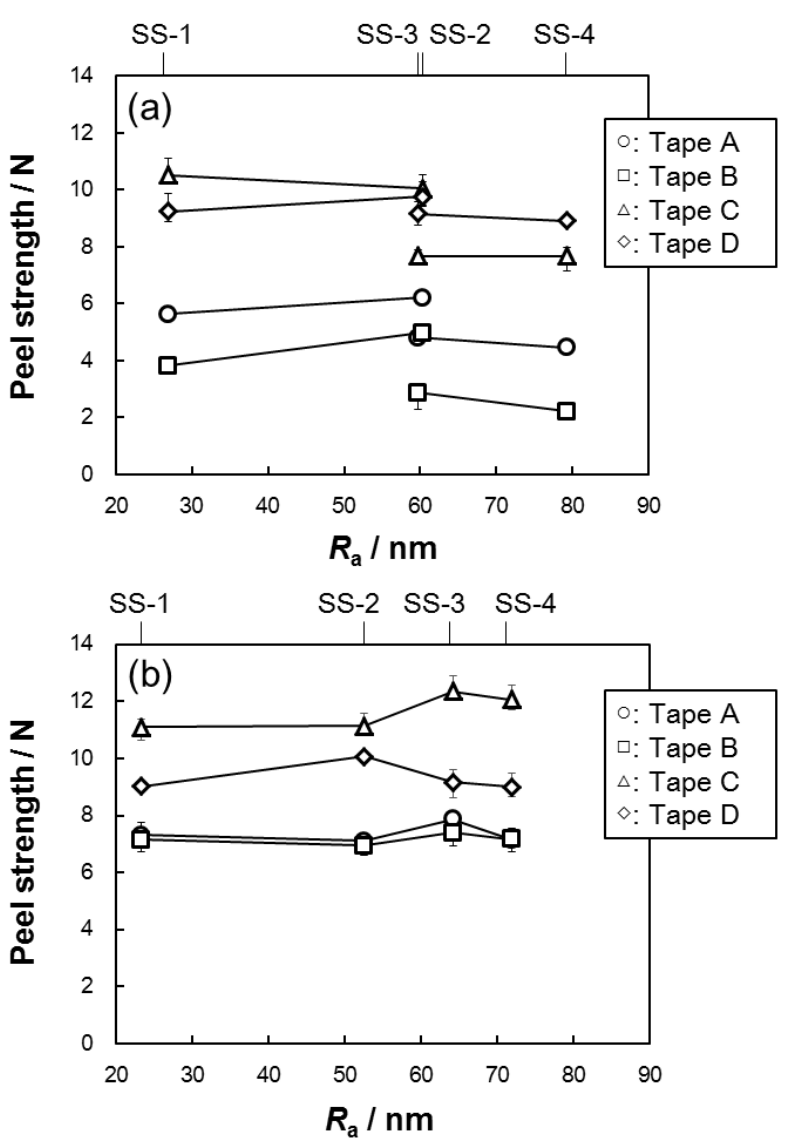

Fig. 8 Effect of surface roughness, $\mathrm{R}_{\mathrm{a}}$ of SS foils on peel strength measured (a) before and (b) after the heat cleaning. The width of Tape A is $24 \mathrm{~mm}$ and that of others is $25 \mathrm{~mm}$.
（2）XPS 分析から, 熱洗浄や超音波洗浄を行っても SS 箔 表面に C 元素が多く存在し, 放置により増加する場 合があった。SSの冷間圧延時に表面の凹部に封じ込 められた潤滑油が, 放置時間にともなって表面に残っ た細孔から染み出すためと考えられる。潤滑油が污染 物質である。

（3）シリコーン系粘着テープは, SS 箔を熱洗浄してもピー ル強度が向上しなかった。表面に污染物質が存在して も，粘着力が強いことを示している。

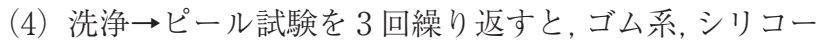
ン系粘着剤は SS 箔表面に残っていることが XPS 測定 から分った。

（5） $R_{\mathrm{a}}$ のピール強度への影響は，小さかった。

\section{文献}

1）大山 正, 森田 茂, 吉武進也, “ステンレスの㧧はな”, 日本規格協会 (1990).

2) 札軒富美夫, 荒木 純, 井上周一, 梁井和博, 新日鉄技報, 389, 77 (2009).

3）増田晃良, 第 35 回粘着技術研究会講演要旨集, 日本粘着テー プ工業会, p.51 (2014).

4) 佐伯邦男, 油化学, 10,83 (1961). 


\title{
$<$ Technical Report $>$
}

\section{Cleaning Method of Stainless Steel Standard Adherend for Peel Test of Pressure-Sensitive Adhesives}

\author{
Shun OKADA *, Yusuke KASHIHARA*, Ai TAKEZAKI*, Yoshiaki URAHAMA **, \\ Tomoyasu HIRAI ***, Syuji FUJII ***, Yoshinobu NAKAMURA*** \\ * Department of Applied Chemistry, Osaka Institute of Technology, \\ 5-16-1, Ohmiya, Asahi-ku, Osaka, 535-8585 Japan \\ ** Graduate School of Engineering, University of Hyogo, \\ 2167, Shosha, Himeji, Hyogo, 671-2201 Japan \\ *** Department of Applied Chemistry, Nanomaterials Microdevices Research Center, \\ Osaka Institute of Technology, \\ 5-16-1, Ohmiya, Asahi-ku, Osaka, 535-8585 Japan \\ (Accepted for publication : October 30, 2018)
}

\begin{abstract}
The purpose of this study is clarifying the contamination source and suitable cleaning method of stainless steel (SS) standard adherend for peel test of pressure-sensitive adhesives (PSA). For this purpose, four kinds of PSA tapes consisting of rubber, polyacrylic polymer, styrenic block copolymer and silicone polymer as base polymer and SS foil as model adherend were used. Two kinds of cleaning methods were employed before peel test: the heat cleaning (the SS foil was wiped with nonwoven fabric containing methyl ethyl ketone three times $\rightarrow$ the same process with toluene was done $\rightarrow$ heated at $175^{\circ} \mathrm{C}$ for $1 \mathrm{~h} \rightarrow$ the cleaning with methyl ethyl ketone and toluene was repeated) and the ultrasonic cleaning in toluene for $1 \mathrm{~h}$. As a result, the peel strength increased after the heat cleaning for three kinds of tapes, on the other hand, hardly increased after the ultrasonic cleaning. From the X-ray photoelectron spectroscopy (XPS) analysis, the content ratio of $\mathrm{C}$ element on SS foil surface was high even after the cleaning process. Further, it increased by the storage at room temperature. The estimated contamination source was the lubricating oil used in the cold-rolling of SS. It was confined in the surface concave portion during the cold-rolling process and oozing out through surface fine pores gradually. It was found that the heat cleaning was effective for lessening the influence of contamination.
\end{abstract}

Key words : Pressure-sensitive adhesive, Peel strength, Adherend, Stainless steel, XPS

(Received : September 10, 2018) 